International Journal of Difference Equations (IJDE).

ISSN 0973-6069 Volume 15, Number 2 (2020), pp. 275-282

(C) Research India Publications

https://dx.doi.org/10.37622/IJDE/15.2.2020.275-282

\title{
The Effect of Intangible Assets on Capital Structure
}

\author{
Yiting Peng', Justine S. Chang ${ }^{2 *}$ and Jia-Ying Zhang ${ }^{3}$ \\ ${ }^{1}$ Chaoyang University of Technology, Department of Accounting, Taiwan. \\ ${ }^{2}$ Chaoyang University of Technology, Department of Accounting, Taiwan. \\ ${ }^{3}$ Chaoyang University of Technology, Department of Accounting, Taiwan.
}

Corresponding addresses:

\begin{abstract}
The study mainly examines whether there is effect of intangible assets on capital structure. Test was conducted on data of electronic industry in Taiwan for seven years prior and after the adoption of IFRS. Result of the study showed that the effect of intangible assets on companies' capital structure is positive, yet not significant, before the adoption of IFRS, but is significantly positive after the adoption of IFRS. Tangible assets also appear to have significantly positive effect on companies' capital structure both before and after the adoption of IFRS. Thus, the importance of intangible assets in measuring companies' solvency upon financing is yet to be studied further.
\end{abstract}

Keywords: intangible assets, capital structure, tangible assets, IFRS

\section{INTRODUCTION}

As the economy transforms and changes, industries have valued more on intangible assets like goodwill, patent and research and development capabilities, etc., which have also gained increasingly importance to corporate value. Thus, companies have speeded up their input to intangible assets significantly, making them to be one of the important factors in measuring competitiveness of publicly listed companies. The feature of intangible assets is their non-existence of actual substance, so their existence may not serve as collaterals. Previous studies mostly explored relationship between assets and capital structures, however, most scholars focus more on tangible fixed assets instead 
of intangible assets. (Jensen, 1986) This study aims to exam whether intangible assets have effect on capital structure. Most studies found that intangible assets' value and contribution to profitability are obvious, but there were few studies to analyze the effect of intangible assets on capital structure. Rampin and Viswanathan (2013) analyzed whether intangible assets have effect on companies' solvency and proposed that there is uncertainty between collateralization of intangible assets and guarantee ability. In comparing to tangible assets, intangible assets are more difficult to recognize completely and effectively estimated and used, so existence of tangible assets can usually support guarantee ability. Rampin and Viswanathan also pointed out that intangible assets can be independent in companies' solvency. Study of Lim et al(2018) found that there is positive relationship between intangible assets and financial leverage and negative relationship between goodwill and financial leverage, meaning that identifiable intangible assets can also support financing and expanding credit like tangible assets. It is understandable that assets are the biggest factor in affecting capital structures, but the effect of intangible assets on capital structure is not yet answered. Thus this study would further explore and focus mainly on electronics industries as study subjects.

\section{DATA}

The study mainly explored the correlation between intangible assets and tangible assets on companies' capital structure before and after the adoption of IFRS and used OLS in regression analysis. Data source is financial data obtained from Taiwan Economic Journal (TEJ) and study period is seven years prior and after the adoption of IFRS and subjects are electronics companies listed in Taiwan Stock Exchange. Because companies with financial crisis may manipulate earnings, so the study eliminate companies of full-cash delivery stock and companies with incomplete financial data. The observed data are 4549, from 648 companies, in the seven years prior to adoption of IFRS, and 5250, from 750 companies, in the seven years after adoption of IFRS.

\section{THEORETICAL FRAMEWORK AND ECONOMETRIC METHODOLOGY TITLE AND AUTHORS}

The study referred to the regression model used by Lim, Macias and Moeller (2020):

Levi $=\alpha+\beta \cdot$ Tani $+\omega \cdot \operatorname{Inti}+\gamma \cdot$ Coni $+\varepsilon i$

Of which, Lev is long-term liability divided by total assets to value a company's liability; Tan is tangible assets divided by total assets; Int is intangible assets divided by total assets to represent a company's intangible assets; while Con is the controllable variable.

Model 1 of this study is to examine the effect of intangible assets on companies' capital 
structure of publicly listed companies in Taiwan before and after the adoption of IFRS.

LEVi, $=\gamma 0+\gamma 1$ INTi, $t+\gamma 2$ SIZEi, $t+\gamma 3$ PROi,t+ +4 GROi,t+ $+\varepsilon i$

Model 2 changed independent variable to tangible assets to examine whether tangible assets have different effects on companies' capital structure publicly listed companies in Taiwan before and after the adoption of IFRS.

$\mathrm{LEVi}, \mathrm{t}=\gamma 0+\gamma 1 \mathrm{TANi}, \mathrm{t}+\gamma 2 \mathrm{SIZEi}, \mathrm{t}+\gamma 3$ PROi, $\mathrm{t}+\gamma 4 \mathrm{GROi}, \mathrm{t}+\varepsilon \mathrm{i}$

Model 3 added tangible assets as independent variable to examine whether tangible assets have different effects on companies' capital structure publicly listed companies in Taiwan before and after the adoption of IFRS.

$\mathrm{LEVi}, \mathrm{t}=\gamma 0+\gamma 1 \mathrm{INTi}, \mathrm{t}+\gamma 2 \mathrm{TANi}, \mathrm{t}+\gamma 3 \mathrm{SIZEi}, \mathrm{t}+\gamma 3$ PROi $, \mathrm{t}+\gamma 5 \mathrm{GRO}, \mathrm{t}+\varepsilon \mathrm{i}$

\section{EMPIRICAL RESULTS AND POLICY IMPLICATIONS}

\subsection{Descriptive analysis}

\begin{tabular}{|l|l|l|l|l|l|l|}
\hline \multicolumn{7}{|c|}{ After adoption of IFRS (2013-2019) } \\
\hline Variable & $\begin{array}{l}\text { No. of } \\
\text { sample }\end{array}$ & Avg. & Med. & Std Dev. & Max & Min \\
\hline LEV & 5250 & 0.069 & 0.039 & 0.080 & 0.588 & 0 \\
\hline INT & 5250 & 0.008 & 0.001 & 0.027 & 0.362 & 0 \\
\hline TAN & 5250 & 0.221 & 0.200 & 0.149 & 0.829 & 0.0005 \\
\hline SIZE & 5250 & 15.261 & 15.021 & 1.435 & 21.949 & 9.756 \\
\hline PRO & 5250 & 0.058 & 0.056 & 0.090 & 0.687 & -0.952 \\
\hline GRO & 5250 & 0.071 & 0.030 & 0.434 & 23.372 & -0.651 \\
\hline
\end{tabular}

Note: LEV: Capital structure; INT: Intangible assets; TAN: Tangible assets; SIZE:

Company scale; PRO: Profitability; GRO: Assets growth rate 
Before adoption of IFRS (2006-2012)

\begin{tabular}{|l|l|l|l|l|l|l|}
\hline Variable & $\begin{array}{l}\text { No. of } \\
\text { sample }\end{array}$ & Avg. & Med. & Std Dev. & Max & Min \\
\hline LEV & 4549 & 0.068 & 0.038 & 0.080 & 0.617 & 0 \\
\hline INT & 4549 & 0.009 & 0.003 & 0.021 & 0.368 & 0 \\
\hline TAN & 4549 & 0.253 & 0.231 & 0.164 & 0.911 & 0 \\
\hline SIZE & 4549 & 15.074 & 14.887 & 1.389 & 21.441 & 7.268 \\
\hline PRO & 4549 & 0.066 & 0.064 & 0.102 & 0.632 & -0.918 \\
\hline GRO & 4549 & 0.143 & 0.054 & 1.594 & 100.788 & -0.581 \\
\hline
\end{tabular}

\subsection{Pearson Correlational Analysis}

\begin{tabular}{|c|l|l|l|l|l|l|}
\hline \multicolumn{7}{|c|}{ Pearson Correlation Coefficient (2013-2019) } \\
\hline Variable & \multicolumn{1}{|c|}{ LEV } & \multicolumn{1}{|c|}{ INT } & TAN & SIZE & PRO & GRO \\
\hline LEV & 1 & & & & & \\
\hline INT & $0.069 * * *$ & 1 & & & & \\
\hline TAN & $0.401 * * *$ & $-0.041 * * *$ & 1 & & & \\
\hline SIZE & $0.224 * * *$ & $0.081 * * *$ & $0.162 * * *$ & 1 & & \\
\hline PRO & $-0.158 * * *$ & $-0.030 * *$ & $-0.126 * * *$ & $0.102 * * *$ & 1 & \\
\hline GRO & 0.003 & 0.016 & $-0.064 * * *$ & -0.017 & $0.212 * * *$ & 1 \\
\hline
\end{tabular}

\begin{tabular}{|c|l|l|l|l|l|l|}
\hline \multicolumn{7}{|c|}{ Pearson Correlation Coefficient (2006-2012) } \\
\hline Variable & \multicolumn{1}{|c|}{ LEV } & \multicolumn{1}{|c|}{ INT } & TAN & SIZE & PRO & GRO \\
\hline LEV & 1 & & & & & \\
\hline INT & $0.038 * * *$ & 1 & & & & \\
\hline TAN & $0.448 * * *$ & $0.028 *$ & 1 & & & \\
\hline SIZE & $0.213 * * *$ & $0.073 * * *$ & $0.174 * * *$ & 1 & & \\
\hline PRO & $-0.169 * * *$ & $-0.085 * * *$ & $-0.178 * * *$ & $0.068 * * *$ & 1 & \\
\hline GRO & -0.003 & -0.015 & -0.020 & $-0.042 * * *$ & $0.098 * * *$ & 1 \\
\hline
\end{tabular}




\subsection{Empirical result analysis}

The following table shows whether intangible assets of publicly listed companies in Taiwan have effect on companies' capital structure before and after the adoption of IFRS. Result of study revealed that coefficient of intangible assets is 0.025 for the years between 2006-2016, not achieving significant level and the coefficient of intangible assets is 0.129 for the years between 2013-2019, reaching 1\% significant level. It appeared that as companies emphasize more on intangible assets, which would weight higher and higher in the companies. Companies would utilize intangible assets more to support financing in obtaining capital, thus producing higher liability ratio. As controlling variables, coefficient of company scales in two study periods are 0.014 and 0.013 , respectively, both reaching $1 \%$ of significant level. It showed that as company scale gets larger, it would lead creditors to believe that the companies can be trusted and companies would obtain more capital via financing. In comparing assets growth rate before and after adoption of IFRS, the coefficient of assets growth rate for the years between 2013-2019 is 0.009, reaching 1\% significant level, showing that intangible assets are helpful for companies to increase their profitability.

\section{Effect of intangibles assets on companies' capital structure for 7 years before} and after the adoption of IFRS

\begin{tabular}{|c|c|c|c|c|}
\hline \multicolumn{4}{|c|}{$\mathbf{L E V}_{\mathrm{i}, \mathrm{t}}=\gamma_{0}+\gamma_{1} \mathrm{INT}_{\mathrm{i}, \mathrm{t}}+\gamma_{2} \mathrm{SIZE}_{\mathrm{i}, \mathrm{t}}+\gamma_{3} \mathrm{PRO}_{\mathrm{i}, \mathrm{t}}+\gamma_{4} \mathrm{GRO}_{\mathrm{i}, t+\varepsilon_{\mathrm{i}}}$} & \multirow[t]{2}{*}{ (1) } \\
\hline & \multicolumn{2}{|c|}{ 2013-2019 } & 2006-2012 & \\
\hline Variable & Coefficient & T value & Coefficient & T value \\
\hline INT & $0.129 * * *$ & 3.282 & 0.025 & 0.453 \\
\hline SIZE & $0.014 * * *$ & 18.090 & $0.013 * * *$ & 15.790 \\
\hline PRO & $-0.171 * * *$ & -14.101 & $-0.145^{* * *}$ & -12.906 \\
\hline GRO & $0.009 * * *$ & 3.470 & $0.001 *$ & 1.728 \\
\hline No. of sample & \multicolumn{2}{|c|}{5250} & \multicolumn{2}{|c|}{4549} \\
\hline Adjusted $\mathrm{R}^{2}$ & \multicolumn{2}{|c|}{0.087} & \multicolumn{2}{|c|}{0.079} \\
\hline F value & \multicolumn{2}{|c|}{$125.782 * * *$} & \multicolumn{2}{|c|}{$98.368^{* * * *}$} \\
\hline
\end{tabular}

Note: $* * *, * *$, and $*$ represent $1 \%, 5 \%$, and $10 \%$ level of significance. Definition of variables: INT, intangible assets; SIZE, company scale; PRO, profitability; GRO, assets growth rate. 
The following table shows the effect of tangible assets on companies' capital structure before and after the adoption of IFRS. According to regression analysis, the coefficients of tangible assets for the two study periods before and after the adoption of IFRS are 0.197 and 0.193 , respectively, both reaching $1 \%$ significant level. It revealed that tangible assets still weigh much importance for publicly listed companies in Taiwan. Although intangible assets gradually become more important in economy nowadays, financing on tangible assets are possibly one of the most secured and safe assurance to companies and banks.

\begin{tabular}{|c|c|c|c|c|}
\hline \multicolumn{5}{|c|}{$\begin{array}{l}\text { Effect of tangibles assets on companies' capital structure for } 7 \text { years before and } \\
\text { after the adoption of IFRS }\end{array}$} \\
\hline \multicolumn{4}{|c|}{$\mathbf{L E V}_{\mathrm{i}, \mathrm{t}}=\gamma_{0}+\gamma_{1} \mathbf{T A N}_{\mathrm{i}, \mathrm{t}+} \gamma_{2}$ SIZE $_{\mathrm{i}, \mathrm{t}}+\gamma_{3} \mathbf{P R O}_{\mathrm{i}, \mathrm{t}}+\gamma_{4} \mathbf{G R O}_{\mathrm{i}, t+\varepsilon_{\mathrm{i}}}$} & (2) \\
\hline & \multicolumn{2}{|c|}{ 2013-2019 } & \multicolumn{2}{|c|}{ 2006-2012 } \\
\hline Variable & Coefficient & T value & Coefficient & T value \\
\hline TAN & $0.193 * * *$ & 28.295 & $0.197 * * *$ & 29.921 \\
\hline SIZE & $0.010 * * *$ & 14.486 & $0.009 * * *$ & 11.393 \\
\hline PRO & $-0.129 * * *$ & -11.320 & $-0.086 * * *$ & -8.192 \\
\hline GRO & $0.011 * * *$ & 4.716 & $0.001 *$ & 1.701 \\
\hline No. of sample & \multicolumn{2}{|c|}{5250} & \multicolumn{2}{|c|}{4549} \\
\hline Adjusted $\mathrm{R}^{2}$ & \multicolumn{2}{|c|}{0.206} & \multicolumn{2}{|c|}{0.230} \\
\hline F value & \multicolumn{2}{|c|}{$341.737 * * *$} & \multicolumn{2}{|c|}{$341.496 * * *$} \\
\hline
\end{tabular}

Note: $* * *, * *$, and $*$ represent $1 \%, 5 \%$, and $10 \%$ level of significance. Definition of variables: INT, intangible assets; SIZE, company scale; PRO, profitability; GRO, assets growth rate.

In order to explore the correlations between intangible assets and tangible assets and companies' capital structure of publicly listed companies in Taiwan before and after the adoption of IFRS, result of regression in the following table showed that coefficients of tangible assets for the two study periods of 2006-2012 and 2013-2019 are 0.197 and 0.196 , respectively, both achieving $1 \%$ significant level. Intangible assets, although they are positively correlated but did not reach significant level in the period between 2006-2012, the coefficient of intangible assets is 0.192 , reaching $1 \%$ significant level, revealing that intangible assets were not that popular in the market in earlier years. Many companies believed that using intangible assets to finance may detriment the performance of market mechanism, therefore intangible assets financing is highly risky and uncertain. (Dixit, 1988) However, as technology develops nowadays the influential power of intangible assets can no longer be underestimated in this intelligence 
economic era while tangible assets still hold the same level of status for electronics industry in Taiwan.

Effect of intangible and tangibles assets on companies' capital structure for 7 years before and after the adoption of IFRS

$\mathbf{L E V}_{\mathrm{i}, \mathrm{t}}=\gamma_{0}+\gamma_{1} \mathrm{INT}_{\mathrm{i}, \mathrm{t}}+\gamma_{2} \mathrm{TAN}_{\mathrm{i}, \mathrm{t}}+\gamma_{3} \mathrm{SIZE}_{\mathrm{i}, \mathrm{t}}+\gamma_{3} \mathbf{P R O}_{\mathrm{i}, \mathrm{t}}+\gamma_{5} \mathrm{GRO}_{\mathrm{i}, \mathrm{t}}+\varepsilon_{\mathrm{i}}$

\begin{tabular}{|c|c|c|c|c|}
\hline & \multicolumn{2}{|c|}{ 2013-2019 } & \multicolumn{2}{c|}{ 2006-2012 } \\
\hline Variable & Coefficient & T value & Coefficient & T value \\
\hline INT & $0.192^{* * *}$ & 5.247 & 0.028 & 0.554 \\
\hline TAN & $0.196^{* * *}$ & 28.631 & $0.197 * * *$ & 29.920 \\
\hline SIZE & $0.010^{* * *}$ & 13.958 & $0.009 * * *$ & 11.315 \\
\hline PRO & $-0.126 * * *$ & -11.068 & $-0.085^{* * *}$ & -8.110 \\
\hline GRO & $0.011^{* * *}$ & 4.598 & $0.001 *$ & 1.702 \\
\hline No. of sample & \multicolumn{2}{|c|}{5250} & \multicolumn{2}{c|}{4549} \\
\hline Adjusted $\mathrm{R}^{2}$ & \multicolumn{2}{|c|}{0.210} & \multicolumn{2}{c|}{0.230} \\
\hline F value & \multicolumn{2}{|c|}{$280.277 * * *$} & \multicolumn{2}{c|}{$273.216 * * *$} \\
\hline
\end{tabular}

Note: $* * * * *$, and $*$ represent $1 \%, 5 \%$, and $10 \%$ level of significance. Definition of variables: INT, intangible assets; SIZE, company scale; PRO, profitability; GRO, assets growth rate.

\section{CONCLUSION}

As intangible assets grow in importance day after day, it's ratio on total assets also grow higher and higher. How to utilize the relationship between intangible assets and capital structure is an important issue nowadays. The company should use intangible assets wisely to create company value and enhance financing ability, thus helping the companies to obtain advantage and development.

\section{REFERENCES}

[1] Jensen, M.C., (1986), Agency costs of free cash flow, corporate finance, and takeovers, American Economic Review, 1986(76), 323-329

[2] Lim, Steve C., Macias, Antonio J, Moeller, Thomas(2020), Intangible assets and capital structure. Journal of Banking \& Finance, September, Vol.118(C).

[3] Dixit, Avinash (1988), A General Model of R\&D Competition and Policy, The Rand Journal of Economics, Autumn 1988, Vol.19(3), p.317. 
[4] Lim, Steve C, Macias, Antonio J, Moeller, Thomas(2014), Intangible assets and capital structure.

https://www.baylor.edu/business/finance/doc.php/231371.pdf

[5] R. Rampini A. and Viswanathan, S., (2013), Collateral and capital structure , Journal of Financial Economics, 109, 466-49. 